\title{
Identification of Conditions for Successful Aphid Control by Ladybirds in Greenhouses
}

\author{
Eric W. Riddick
}

National Biological Control Laboratory, Jamie Whitten Delta States Research Center, Agricultural Research Service, USDA, Stoneville, MS 38776, USA; eric.riddick@ars.usda.gov; Tel.: +1-662-686-3646; Fax: +1-662-686-5281

Academic Editor: Brian T. Forschler

Received: 14 December 2016; Accepted: 20 March 2017; Published: 28 March 2017

\begin{abstract}
As part of my research on the mass production and augmentative release of ladybirds, I reviewed the primary research literature to test the prediction that ladybirds are effective aphid predators in greenhouses. Aphid population reduction exceeded $50 \%$ in most studies and ladybird release rates usually did not correlate with aphid reduction. The ratio of aphid reduction/release rate was slightly less for larvae than adults in some studies, suggesting that larvae were less effective (than adults) in suppressing aphids. Some adult releases were inside cages, thereby limiting adult dispersion from plants. Overall, the ratio of aphid reduction/release rate was greatest for ladybird adults of the normal strain (several species combined), but least for adults of a flightless Harmonia axyridis strain. The combined action of ladybirds and hymenopteran parasitoids could have a net positive effect on aphid population suppression and, consequently, on host (crop) plants. However, ladybird encounters with aphid-tending or foraging ants must be reduced. Deploying ladybirds to help manage aphids in greenhouses and similar protective structures is encouraged.
\end{abstract}

Keywords: Aphididae; biological control; Coccinellidae; organic agriculture; pest management; predation

\section{Introduction}

Culturing plants in greenhouses, glasshouses, or hothouses has existed in Europe and Asia since the early 19th century, with expansion into North America and other regions of the world in recent years [1-3]. Despite the protective, semi-enclosed environment in greenhouses, a number of herbivorous pests routinely invade them and infest crop and non-crop plants. Some of the traditional pests of importance in greenhouses include spider mites, whiteflies, thrips, and aphids, all of which have great potential to reach outbreak densities and result in production losses, if not controlled [4].

Of the approximately 4700 species in the Family Aphididae, nearly 100 are significant agricultural pests [5]. In greenhouses, the most important species attacking vegetable crops are Aphis gossypii Glover, Macrosiphum euphorbiae (Thomas), Aulacorthum solani (Kaltenbach), and Myzus persicae Sulzer [6]; those attacking ornamentals are A. gossypii, M. euphorbiae, A. solani, M. persicae, Brachycaudus helichrysi (Kaltenbach), Macrosiphoniella sanborni (Gillette), and Macrosiphum rosae (L.) [7]. Important species attacking small fruits (e.g., strawberries) in greenhouses are Chaetosiphon fragaefolii (Cockerell), A. gossypii, M. euphorbiae, M. persicae, and Myzus ascalonicus Doncaster [8]. These species can have a dramatic impact on crop production via direct feeding injury to crop plants, the transmission of plant viruses between individual plants, and the rapid development of resistance to insecticides [9-11]. Honeydew, excreted by aphids, adheres to plant foliage as well as some fruits (e.g., strawberries), and promulgates the growth of sooty mold. Sooty mold is unsightly and renders some fruit unsuitable for sale in traditional markets.

Due to their potential to rapidly develop resistance to insecticides, there is growing interest in using non-insecticidal control methods, such as biological control, to suppress aphids in 
greenhouses [12,13] and similar structures. Aphid parasitoids are sometimes used for this purpose [14]; in recent years, mass-reared hymenopteran parasitoids (Family Aphidiidae, and Family Aphelinidae) have become the option of choice, rather than predators $[15,16]$. However, there are several drawbacks to using aphid parasitoids. The cost of rearing aphid parasitoids for augmentative release in greenhouses can be high, because host plants and live hosts (aphids) must be supplied to maintain colonies in commercial mass production. There are only a few suitable factitious hosts or artificial media for aphids or developing parasitoids. Another problem is related to host plant defenses against aphid herbivory; glandular trichomes can greatly reduce parasitism rates and even increase parasitoid mortality rates [17]. Aphid parasitoids are commonly attacked by hyperparasitoids in open field and greenhouse settings [14]. Additionally, immature parasitoids often succumb to intraguild predation from generalist predators, such as ladybird beetles, i.e., lady beetles (Family Coccinellidae), but net consequences of intraguild predation could be positive or negative to aphid suppression in open field situations $[16,18]$.

Ladybird beetles are common biological control agents of aphids in natural field settings [19-28]. Many researchers claim that ladybirds are incapable of regulating aphid populations under natural field conditions for reasons relating to their voracity, search efficiency, predation capacity, and reproductive rate [29-33], but there are a few reported examples of apparent regulation [34,35]. Nevertheless, the ability to regulate aphid populations is not essential if repeated (inundative) releases of ladybirds into a greenhouse delays or prevents aphid outbreaks. Historical evidence suggests that several ladybird beetle species have the potential to reduce aphid populations in greenhouses or glasshouses [36,37]. We consider the ladybird beetle's ability to cause rapid declines in aphid population density (and thereby diverting aphid outbreaks), via repeated ladybird releases or increasing the ladybird release rate, to be an alternative gauge of effectiveness [38,39] in greenhouses and glasshouses.

The efficacy of ladybirds as aphid predators in greenhouses and glasshouses has been reviewed previously [40], but this current study represents a more comprehensive review of the published literature using the United States Department of Agriculture (USDA), National Agricultural Library, Digitop Literature Database (Navigator platform) to assess the abstracts that include the search terms "Coccinellidae and greenhouse" or "Coccinellidae and glasshouse". The Navigator platform is associated with the following literature databases: AGRICOLA, AGRIS, BIOSIS Previews, CAB Abstracts, Fish \& Fisheries, GEOBASE, EBSCO Environment, MEDLINE, Scopus, Web of Science, Wildlife and Ecology, FSTA, Treesearch, and Zoological Record.

In this review, the prediction that ladybird beetles can be effective predators of aphids in greenhouses and glasshouses was tested. Biotic factors including host plant defenses, ladybird life stage at release, interactions with other predators, aphid parasitoids, and ants could limit ladybird effectiveness. A generalized schematic of the positive (+), neutral (o), or negative (-) interactions that could arise between these factors is presented in Figure 1. Prior research conducted primarily in the laboratory and in open field settings suggests that host plant defenses could have negative or neutral effects on aphids as well as ladybirds [41]. Also, aphid density has a positive effect on ladybirds [21,22], but the effect can become negative if prey becomes scarce, resulting in starvation or cannibalism amongst immature ladybirds. Aphid parasitoids have negative effects on their aphid hosts $[14,16]$. Ladybirds can have negative effects on aphid parasitoids developing inside aphid hosts, through aphid predation [18]. Aphid-tending ants could have positive effects on aphids which they tend [42], but negative effects on most species of aphidophagous ladybirds [43]. Foraging predatory ants, which kill rather than tend aphids, could have negative effects on aphid density and on the predation potential of ladybirds [44]. 


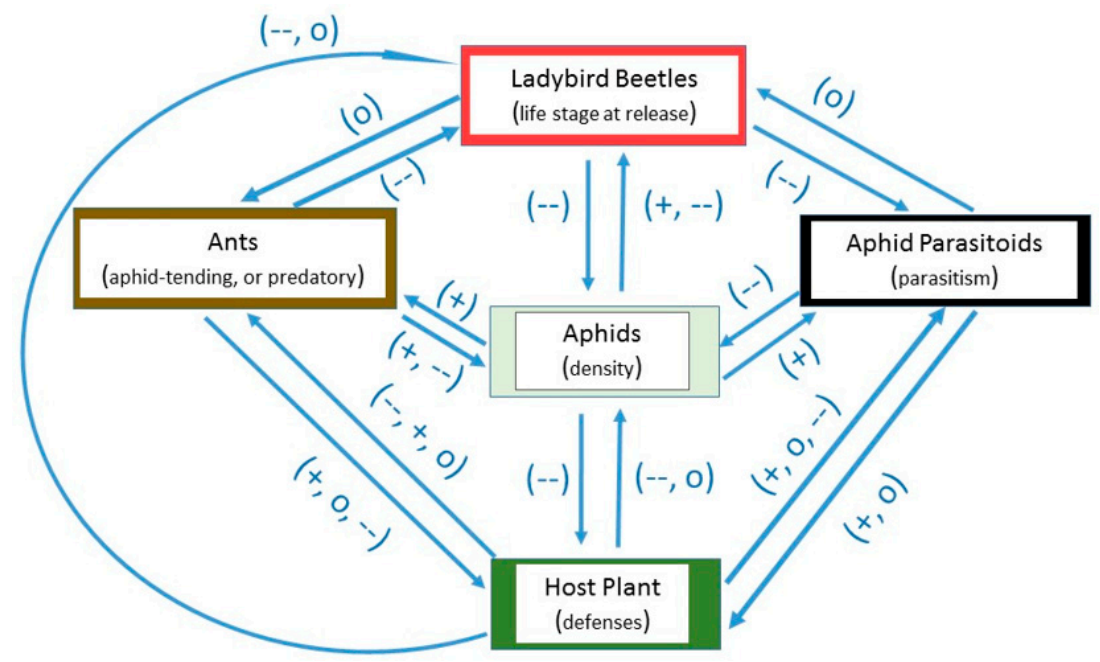

Figure 1. Generalized schematic of the positive (+), neutral (o), or negative (-) interactions that could occur between host plants, aphids, ladybirds, aphid parasitoids, and ants in greenhouses.

Relevant studies providing data on ladybird releases were tabulated for an assessment of the capacity of ladybirds to reduce aphid populations. Percent aphid reduction was calculated using one of two methods: (1) When control cages or control greenhouses were used, and aphid density was equilibrated at the onset of the experiment, percent aphid reduction was calculated from aphid density on control and test plants [(control - test)/control $(\times 100)]$ at post-release evaluation; $(2)$ In the absence of controls, or if aphid density was variable at the onset of the experiment, percent aphid reduction was calculated from aphid density on plants before releasing ladybirds (pre-release) and after releasing them (post-release) [(pre-release - post-release)/pre-release $(\times 100)]$.

To compare ladybird efficacy across studies listed in Table 1, I used the Pearson Product Moment Correlation to determine if release rate and aphid population reduction were correlated. A Student's $t$-test compared the ratio of aphid population reduction/release rate between larvae and adults. Correlations and mean values were significantly different when $p<0.05$. SigmaStat 3.0.1 (interfaced through Sigma Plot 12, SAS Institute Inc., Cary, NC, USA) software assisted with data analysis.

\section{Factors Potentially Affecting Ladybird Success in Greenhouses}

\subsection{Host Plant Defenses}

Defenses that plants deploy to reduce herbivory can alter the effectiveness of ladybird beetles [41]. Foliage of faba bean Vicia faba L. 79S4 cultivar (partially resistant) reduced the reproductive rate of the black bean aphid Aphis fabae Scopoli in pots enclosed in cages [45]. Although the mechanism of resistance was not indicated, perhaps allelochemicals in cultivar 79S4 foliage reduced A. fabae herbivory. Allelochemicals are secondary plant compounds that are sometimes toxic to aphids, and thereby reduce herbivory. These compounds may or may not affect predation capacity of ladybirds which consume aphids on defended plants. A release ratio of 1:1 (1 Coccinella septempunctata L. neonate larva: 1, two-day old $A$. fabae adult) per plant, reduced aphid density by $57.1 \%$ on the partially resistant cultivar, but just $33 \%$ on the susceptible cultivar ( $V$. faba, cv. major) in nine days, when compared against control plants, caged plants without ladybird beetles (Table 1). This observation suggests that the combination of partial $V$. faba resistance and C. septempunctata predation was more effective in reducing $A$. fabae density than either method alone [45]. Thus, host plant defense did not reduce predation capacity of $C$. septempunctata in this study.

Morphological plant defenses, such as the degree of "waxiness" on the leaf surface, can affect predation potential of ladybirds foraging on plants. For example, adults of the convergent lady beetle 
Hippodamia convergens Guérin-Ménéville foraged more effectively for pea aphids Acyrthosiphon pisum (Harris) on caged pea Pisum sativum L. plants with a reduced leaf wax phenotype than on those with a normal leaf wax phenotype [46]. Waxy leaves may impede the movement of $H$. convergens on plants in cages, thereby reducing its effectiveness as an aphid predator.

Plant epidermal hairs (i.e., plant trichomes) can alter the foraging behavior of coccinellids on plants and are known to impale or trap some aphid species [41]. Trichomes may or may not affect predation capacity of ladybirds which forage for aphids on defended plants. Coccinellid adults (e.g., H. convergens) spent less time foraging on potted wild potato Solanum berthaultii Hawkes containing a high density of glandular trichomes on its leaves and stems than on an interspecific hybrid of cultivated potato Solanum tuberosum L. $\mathrm{x}$ wild potato $S$. berthaultii $\mathrm{F}_{3}$, containing a moderate density of glandular trichomes, or on $S$. tuberosum, containing no glandular trichomes [47]. Thus, H. convergens predation capacity was presumably reduced on potato foliage containing high trichome density.

A reduction in foraging time on plants containing trichomes can result in a reduction of aphid control, as shown for 2nd instar larvae. Note that 2nd instar larvae of the ladybird Coleomegilla maculata DeGeer did not remain on potted cucumber Cucumis sativus L. plants long enough to suppress densities of the melon/cotton aphid A. gossypii [48]. Glandular trichomes on C. sativus leaves were perceived as being "irritating" to C. maculata larvae. The effect of trichomes on ladybird larvae is species specific. In the same study, C. sativus glandular trichomes did not negatively affect predation capacity of 2nd instar larvae of other ladybirds, such as Cycloneda sanguinea (L.) and Adalia bipunctata (L.). Aphid populations were reduced by $50.4 \%$ and $36.0 \%$ in 11 days by C. sanguinea and A. bipunctata, respectively. Thus, cucumber trichomes have differential effects on ladybird larvae; $C$. maculata were affected negatively, but $C$. sanguinea and $A$. bipunctata were not.

The Antares, CNPA 7H, or DeltaOpal cultivars of cotton Gossypium hirsutum L., representing plants with glabrous (low), hirsute (moderate), and pilose (high) trichome density, did not reduce the predation capacity of C. sanguinea and H. convergens [49]. Young plants (approximately 30 days old) were infested with 100 aphids (A. gossypii) and two days later, a single $H$. convergens or $C$. sanguinea adult female was released onto infested plants. $H$. convergens and $C$. sanguinea females reduced the aphid population on plants by an average of $87 \%$ and $93.5 \%$, respectively, regardless of trichome density and within two days of release, in comparison to aphid density on plants not inoculated with a ladybird.

To summarize this section, host plant defenses can affect the ability of ladybirds to reduce aphid population density in greenhouses. However, the negative reports are occasional as mentioned herein. Based upon a comparative analysis of the data listed in Table 1 for this section (Host plant defenses), aphid population reduction did not correlate with release rate $(r=-0.34 ; p=0.28 ; n=12)$; and ladybird larvae were not significantly less effective than adults, based on a ratio of aphid reduction/release rate $(t=1.13 ; \mathrm{df}=10 ; p=0.29$; Figure 2; Table 1 .
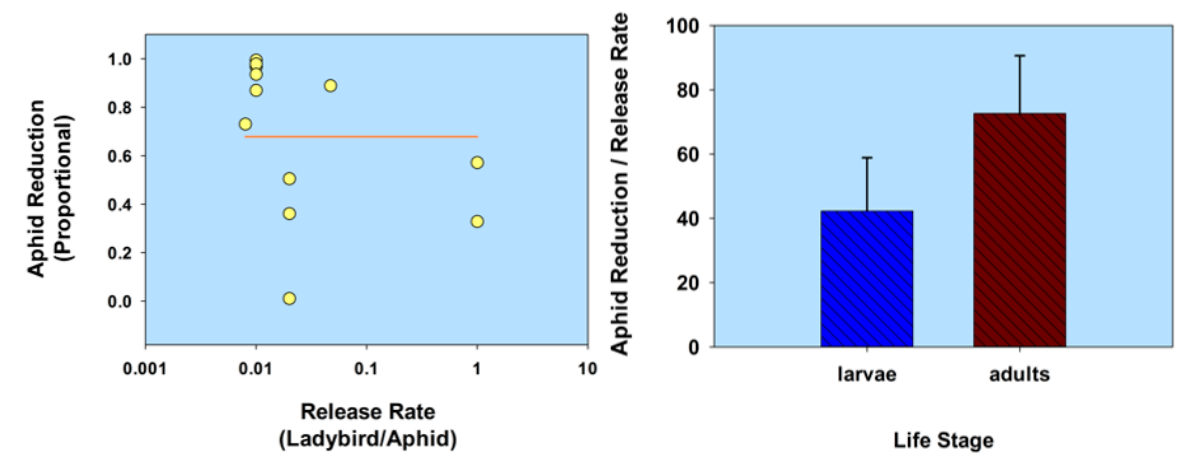

Figure 2. Scatterplot of release rate vs. aphid population reduction and bar graph of ladybird life stage vs. the ratio of aphid reduction/release rate, in relation to host plant defenses. The release rate is plotted on a common logarithmic scale. Data based on five studies and 12 observations (see Table 1). 


\subsection{Life Stage}

\subsubsection{Normal Strain}

Life stage and release rate could affect the ability of ladybirds to suppress aphid populations. In a manipulative experiment involving potted chrysanthemums (Chrysanthemum indicum L. cultivar BGA Tuneful), 2nd instar larvae of three species, C. maculata, A. bipunctata, and C. sanguinea reduced the density of $M$. persicae [48]. For example, at a release density of 10 larvae (2nd instars) per replicate pot, with approximately $1000 \mathrm{M}$. persicae per pot (four plant cuttings per pot), the density of aphids was reduced by $97 \%, 98 \%$, and $99 \%$ in seven days, due to predation by C. maculata, A. bipunctata, and C. sanguinea, respectively (see Table 1). In the control pots (with approximately 1000 aphids per pot, without ladybird larvae), M. persicae density increased 2.1-fold in seven days. This study demonstrates the potential benefits of using ladybird larvae. Ladybird adults tended to readily depart from plants soon after being released. Therefore, predation potential of one species, A. bipunctata, was estimated in cages. When compared against control cages, A. bipunctata adults in test cages were highly effective, reducing $M$. persicae by $73.0 \%$ to $88.8 \%$ in two weeks. When mobility is restricted to cages, adult ladybirds are generally as effective as larvae in reducing $M$. persicae density.

In another study, $9.0 \mathrm{~m}^{2}$ plots were set up to test the efficacy of two ladybird beetle species, C. septempunctata and A. bipunctata [50]. A single release of 1st instar larvae of both species reduced aphid populations on crop plants. When aphid density was compared between control, commercial greenhouses (no predators released) and experimental greenhouses, both ladybird species curbed population growth of $M$. persicae on chrysanthemum (Chrysanthemum morifolium Ramat.) and sweet pepper (Capsicum annuum L.), respectively, in 8-10 days at several release rates. The release rate (number of ladybirds/ number of aphids) did not appear to have an effect on aphid reduction.

In a preliminary study, two ladybirds, Lemnia biplagiata (Swartz) and Leis dimidiata (F.), were tested for their capacity to reduce melon aphid (A. gossypii) numbers on cucumbers [51]. The authors stated that releases of 2 nd instar larvae of L. dimidiata were more effective than adults, since adults tended to disperse from plants at low aphid density. The larvae continued to search foliage for aphids, even at low aphid density. For L. dimidiata, a release ratio of 1:10 or 1:20, ladybird: aphid was suitable to suppress $A$. gossypii populations by $85 \%-90 \%$. Unfortunately, the authors didn't provide information on A. gossypii density at release or post-release of L. dimidiata. Despite this, the authors recommend using both L. dimidiata and L. biplagiata to suppress aphid populations on cucumbers, peppers, and eggplants [51].

Harmonia axyridis (Pallas) larvae (274 3rd and 4th instars) and adults (726 overwintered adults) were released on strawberry (Fragaria $x$ ananassa Duchesne) plants to reduce populations of two aphid species, Aphis forbesi Weed and Chaetosiphon minor (Forbes) [52]. In one week, aphid density (both species combined) decreased from nearly 1200 to 200 aphids per 20 plants. However, aphids began to rebound in a few weeks, because released larvae metamorphosed into pupae and then adults. Adults (both newly emerged and overwintered adults) then dispersed from the low-lying plants, leaving the greenhouse (since the greenhouse was open). Nevertheless, aphid densities decreased again as enough newly emerged adults remained in the greenhouse long enough to oviposit on plants; larvae hatching from these eggs helped reduce aphid densities. In another greenhouse at the same location and in the same season, $H$. axyridis larvae (750 3rd and 4th instars) and no adults were released onto strawberry plants. Aphid density decreased over 29 days from approximately 1300 to 200 aphids per 20 plants as a result of $H$. axyridis predation, suggesting that many of the larvae remained on the plants, fed on aphids, and pupated successfully; emerging adults contributed to aphid control as well. Note that the initial release rate was high (0.58 larvae/aphids), the time frame of the study was 29 days, and aphid reduction was $85 \%$. Apparently, newly emerged $H$. axyridis adults were prevented from exiting the greenhouse. 
Table 1. Greenhouse studies providing reliable data on ladybird release ratio, rate, and percent aphid reduction within a specified time frame, relative to host plant defenses, life stage, and presence of other predators.

\begin{tabular}{|c|c|c|c|c|c|c|c|c|}
\hline Factors & Ladybird & Aphid & Plant & Release Ratio (L:A) & Release Rate (L/A) & Aphid Reduction (\%) ${ }^{1}$ & Time Frame (Days) & Reference \\
\hline \multirow[t]{5}{*}{ Host plant defenses } & Coccinella septempunctata (1st instars) & Aphisfabae & $\begin{array}{c}\text { Vicia faba, c.v. major } \\
\text { V. faba, c.v. } 79 S 4 \text { [in cages] }\end{array}$ & $\begin{array}{l}1: 1 \\
1: 1\end{array}$ & $\begin{array}{l}1.0 \\
1.0\end{array}$ & $\begin{array}{l}32.8 \\
57.1\end{array}$ & $\begin{array}{l}9 \\
9\end{array}$ & Shannag and Obeidat $2008[45]$ \\
\hline & $\begin{array}{l}\text { Cycloneda sanguinea (2nd instars) } \\
\text { Coloomegilla maculata (2nd instars) } \\
\text { Adalia bipunctata (2nd instars) }\end{array}$ & Aphis gossypii & Cucumis sativus & $\begin{array}{l}1: 50 \\
1: 50 \\
1: 50\end{array}$ & $\begin{array}{l}0.02 \\
0.02 \\
0.02\end{array}$ & $\begin{array}{c}50.45^{+} \\
0^{+} \\
36.02^{+}\end{array}$ & $\begin{array}{l}11 \\
11 \\
11\end{array}$ & Gurney and Hussey 1970 [48] \\
\hline & $\begin{array}{l}\text { C. sanguinea (2nd instars) } \\
\text { C. maculata (2nd instars) } \\
\text { A. bipunctata (2nd instars) }\end{array}$ & Myzus persicae & $\begin{array}{l}\text { Chrysanthemum indicum, } \\
\text { c.v. BGA Tuneful }\end{array}$ & $\begin{array}{l}1: 100 \\
1: 100 \\
1: 100\end{array}$ & $\begin{array}{l}0.01 \\
0.01 \\
0.01\end{array}$ & $\begin{array}{l}99.36^{+} \\
96.64^{+} \\
97.77^{+}\end{array}$ & $\begin{array}{l}07 \\
07 \\
07\end{array}$ & Gurney and Hussey $1970[48]$ \\
\hline & A. bipunctata (adults) & M. persicae & C. indicum [in cages] & $\begin{array}{l}1: 117 \\
1: 21\end{array}$ & $\begin{array}{l}0.008 \\
0.047\end{array}$ & $\begin{array}{l}73.02^{+} \\
88.85^{+}\end{array}$ & $\begin{array}{l}144 \\
14\end{array}$ & Gurney and Hussey $1970[48]$ \\
\hline & $\begin{array}{c}\text { C. sanguinea (adults) } \\
\text { Hippodamia convergens (adults) }\end{array}$ & A. gossypii & Gossypium hirsutum & $\begin{array}{l}1: 100 \\
1: 100\end{array}$ & $\begin{array}{l}0.01 \\
0.01\end{array}$ & $\begin{array}{l}93.5^{+} \\
86.9^{+}\end{array}$ & $\begin{array}{l}2 \\
2\end{array}$ & Boiça et al. 2004 [49] \\
\hline \multirow[t]{7}{*}{ Life stage (normal strain) } & $\begin{array}{l}\text { C. septempunctata (1st instars) } \\
\text { A. bipunctata (1st instars) }\end{array}$ & M. persicae & Capsicum аппиит & $\begin{array}{l}1: 10 \\
1: 20 \\
1: 10 \\
1: 20\end{array}$ & $\begin{array}{l}0.10 \\
0.05 \\
0.10 \\
0.05\end{array}$ & $\begin{array}{l}93.7^{+} \\
35.1^{+} \\
97.5^{+} \\
85.7^{+}\end{array}$ & $\begin{array}{l}10 \\
10 \\
10 \\
10\end{array}$ & Hämäläinen 1977 [50] \\
\hline & $\begin{array}{l}\text { C. septempunctata (1st instars) } \\
\text { A. bipunctata (1st instars) }\end{array}$ & M. persicae & $\begin{array}{l}\text { Chrysanthemum } \\
\text { morifolium }\end{array}$ & $\begin{array}{l}1: 43 \\
1: 16 \\
1: 75\end{array}$ & $\begin{array}{l}0.023 \\
0.062 \\
0.013\end{array}$ & $\begin{array}{l}90.7 \\
91.5 \\
77.3 \\
\end{array}$ & $\begin{array}{l}08 \\
08 \\
08\end{array}$ & Hämäläinen 1977 [50] \\
\hline & $\begin{array}{l}\text { C. septempunctata (adults) } \\
\text { A. bipunctata (adults) }\end{array}$ & M. persicae & C. morifolium & $\begin{array}{l}1: 12 \\
1: 50 \\
1: 39\end{array}$ & $\begin{array}{l}0.083 \\
0.02 \\
0.025\end{array}$ & $\begin{array}{l}86.95 \\
94.0 \\
46.15\end{array}$ & $\begin{array}{l}08 \\
08 \\
08\end{array}$ & Hämäläinen 1977 [50] \\
\hline & Leis (Harmonia) dimidiata (2nd instars) & A. gossypii & C. sativus & $\begin{array}{l}1: 10 \\
1: 20\end{array}$ & $\begin{array}{l}0.10 \\
0.05\end{array}$ & $\begin{array}{l}85-90 \\
85-90\end{array}$ & $\begin{array}{l}- \\
-\end{array}$ & Kuznetsov \& Hong 2002 [51] \\
\hline & Harmonia axyridis (3rd, 4th instars) & $\begin{array}{l}\text { Chaetosiphon minor, } \\
\text { Aphis forbesi }\end{array}$ & Fragaria $\times$ ananassa & 1:1.73 & 0.58 & 84.6 & 29 & Seo \& Youn 2002 [52] \\
\hline & C. maculata (3rd instars) & A. gossypii & F. $\times$ ananassa [in cages] & $\begin{array}{l}1: 15 \\
1: 5 \\
1: 3 \\
\end{array}$ & $\begin{array}{l}0.07 \\
0.20 \\
0.33 \\
\end{array}$ & $\begin{array}{l}46.3 \\
87.3 \\
96.4 \\
\end{array}$ & $\begin{array}{l}14 \\
14 \\
14 \\
\end{array}$ & Rondon et al. 2005 [53] \\
\hline & H. axyridis (adults) & M. persicae & C. апnиит [in cages] & $\begin{array}{l}1: 20 \\
1: 40 \\
1: 80 \\
1: 160 \\
1: 320 \\
1: 640\end{array}$ & $\begin{array}{l}0.05 \\
0.02 \\
0.01 \\
0.006 \\
0.000 \\
0.001\end{array}$ & $\begin{array}{l}99.2^{+} \\
99.4^{+} \\
99.5^{+} \\
98.9^{+} \\
95.3^{+} \\
85.7^{+}\end{array}$ & $\begin{array}{l}10 \\
10 \\
10 \\
10 \\
10 \\
10\end{array}$ & LaRock et al. 2003 [54] \\
\hline
\end{tabular}


Table 1. Cont.

\begin{tabular}{|c|c|c|c|c|c|c|c|c|}
\hline Factors & Ladybird & Aphid & Plant & Release Ratio (L:A) & Release Rate (L/A) & Aphid Reduction $(\%)^{1}$ & Time Frame (Days) & Reference \\
\hline \multirow[t]{4}{*}{$\begin{array}{c}\text { Life stage } \\
\text { (flightless strain) }\end{array}$} & $\begin{array}{l}\text { H. axyridis (1st instars) } \\
\text { (flightless strain) }\end{array}$ & A. gossypii & C. satious & $\begin{array}{l}1: 2.5 \\
1: 0.5 \\
1: 0.25\end{array}$ & $\begin{array}{l}0.4 \\
2.0 \\
4.0\end{array}$ & $\begin{array}{l}65.0^{+} \\
98.3^{+} \\
99.5^{+}\end{array}$ & $\begin{array}{l}05 \\
05 \\
05\end{array}$ & Kuroda \& Miura 2003 [55] \\
\hline & $\begin{array}{l}\text { H. axyridis (2nd instars) } \\
\text { (flightless strain) }\end{array}$ & Lipaphis erysimi & Brassica rapa & 1:0.14 & 7.1 & 98.0 & 21 & Adachi-Hagimori et al. 2011 [56] \\
\hline & $\begin{array}{l}\text { H. axyridis (adults) } \\
\text { (flightless strain) }\end{array}$ & $\begin{array}{l}\text { M. persicae } \\
\text { L. erysimi }\end{array}$ & B. rapa & $\begin{array}{l}1: 3.9 \\
1: 3.9 \\
\end{array}$ & $\begin{array}{l}0.25 \\
0.25 \\
\end{array}$ & $\begin{array}{c}72.0-98.0 \\
81.0 \\
\end{array}$ & $\begin{array}{l}21 \\
21 \\
\end{array}$ & Adachi-Hagimori et al. 2011 [56] \\
\hline & $\begin{array}{l}\text { H. axyridis (2nd instars) } \\
\text { (flightless strain) } \\
\text { H. axyridis (adults) } \\
\text { (flightless strain) }\end{array}$ & Aulacorthum solani & Solanum melongena & $\begin{array}{l}1: 5 \\
1: 25\end{array}$ & $\begin{array}{l}0.20 \\
0.04\end{array}$ & $\begin{array}{l}66.7 \\
66.7\end{array}$ & $\begin{array}{l}21 \\
21\end{array}$ & Seko et al. 2014 [57] \\
\hline Other predators & $\begin{array}{l}\text { Coccinella transversoguttata (adults) } \\
\text { C. transversoguttata (adults) plus one hemipteran } \\
\text { C. transversoguttata (adults) plus two hemipterans }\end{array}$ & M. persicae & Beta vulgaris & $\begin{array}{l}1: 28.5 \\
1: 28.5 \\
1: 28.5\end{array}$ & $\begin{array}{l}0.035 \\
0.035 \\
0.035\end{array}$ & $\begin{array}{l}100 \\
100 \\
100\end{array}$ & $\begin{array}{l}6 \\
6 \\
6\end{array}$ & Tamaki and Weeks 1972 [58] \\
\hline
\end{tabular}

L, Ladybird; A, Aphid. ${ }^{1}$ Percent aphid reduction calculated using one of two methods: ${ }^{\dagger}$ When control cages or control greenhouses were used, and aphid density was equilibrated at the onset of the experiment, percent aphid reduction was calculated from aphid density on control and test plants [(control - test)/control $(\times 100)]$ at post-release evaluation. In the absence of controls, or if aphid density was variable at the onset of the experiment, percent aphid reduction was calculated from aphid density on plants before releasing ladybirds (pre-release) and after releasing them (post-release) [(pre-release - post-release)/pre-release $(\times 100)]$. 
In a study involving aphids on strawberry plants, in replicate ( $1 \mathrm{~m}^{3}$ nylon) cages, C. maculata 3rd instars showed promise in reducing the cotton aphid, A. gossypii, particularly at high population densities [53]. Two weeks after releasing C. maculata, A. gossypii densities were reduced by $87 \%$ and $96 \%$, at a release rate of 0.20 and 0.33 ladybird/aphid density, respectively. At a lower release rate (0.07 ladybird/aphid), the A. gossypii population was reduced by $47 \%$.

In another study, $H$. axyridis or C. septempunctata was released to manage primarily A. gossypii on strawberry plants [59]. The practice of removing "old" leaves from plants (i.e., cultural control) was useful in managing low density populations. At high densities, H. axyridis or C. septempunctata was released on leaves, flowers, and fruit [59]. Neither the life stage of the ladybird nor the quantity released was stated in this study. In a companion study, the researchers [60] released C. septempunctata (life stage not mentioned) to suppress A. gossypii and Aphis craccivora Koch on sweet pepper (C. annuum). Although the quantity or life stage of the ladybirds released was not specifically mentioned, the authors suggest that both ladybird species contributed to aphid population reduction in the test greenhouse in contrast to the control greenhouse (without ladybirds). Because of the lack of ladybird release rates, this study was not listed in Table 1.

The population density of $M$. persicae was reduced significantly by $H$. axyridis (presumably adults) on chile Capsicum annum L. plants held in screened cages [54]. In the experiment, plants were inoculated with $H$. axyridis and $M$. persicae at ladybird: aphid ratios ranging from 1:20 to 1:640 in replicated treatment cages (see Table 1). In comparison to control cages (lacking H. axyridis), aphid density was significantly reduced by at least 95\% at all densities, except the 1:640 density (85.7\%), over a 10-day sampling period. This study shows the potential of $H$. axyridis adults as a predator of M. persicae on chile plants. It is very unlikely that the same positive results would be achievable if chile plants were not enclosed in cages, because of the propensity of $H$. axyridis adults to fly away from plants, as documented in other studies.

Cucumber (Cucumis satious L.) plants artificially infested with A. gossypii at a density of 50 aphids per plant were exposed to neonate larvae (emerging from egg clutches) of $H$. axyridis of a lab-cultured flightless strain, in replicate greenhouses, including a control greenhouse of identical dimensions (but no ladybird releases) [55]. Releases of 5 or 10 (rather than 1) egg clutches, containing an average of 20 eggs/clutch, per cucumber plant, proved effective, as 1st instar larvae hatched and consumed A. gossypii within five days post-release. By the eighth day, A. gossypii began to increase their densities again, suggesting that multiple releases of $H$. axyridis egg clutches and/or 1st instar larvae would be necessary to further reduce the aphid population.

\subsubsection{Flightless Strain}

Both larvae and adults of a flightless strain of $H$. axyridis were tested as biological control agents against $M$. persicae and turnip aphid Lipaphis erysimi (Kaltenbach) on seedlings of non-heading Brassica rapa L. (2 cultivars) [56]. At an average initial density of 1.4-7.8 aphids per plant or 1.4 aphids per plant, release rates of $2 \mathrm{H}$. axyridis adults per $\mathrm{m}^{2}$ or 10 larvae per $\mathrm{m}^{2}$ area of plot ( 80 plants $/ \mathrm{plot}$ ) were sufficient to prevent significant increases in aphid densities over three weeks. In comparison to control plots (no releases), M. persicae density was $72 \%-98 \%$ lower and L. erysimi density was $81 \%$ lower in test plots with one release of $H$. axyridis adults. Flightless $H$. axyridis adults remained on experimental plants, in release plots, much longer than larvae [56].

In another study, 2nd instar larvae or adults of a flightless strain of $H$. axyridis were tested against A. solani on cultivated eggplants Solanum melongena (L.) [57]. A total of 600 larvae or 120 adults were released three times in the test plots, respectively; no predators were released in the control plots. This translated into $10 \mathrm{H}$. axyridis larvae per plant versus 2 adults per plant (60 plants per plot). Approximately 21 days after the third release of ladybird larvae and adults into separate test plots, 30 aphids per leaf (median value) were on plants in the control (no-release) plots, and 10 aphids per leaf (median value) were on plants in both test plots (larvae release plot, and adult release plot). Thus, A. solani population density was reduced by $66.7 \%$ in both test plots, when compared against the control 
plot (Table 1). Approximately 35 days after the third release of larvae and adults, A. solani density was reduced by $70 \%$ and $60 \%$ in the larval release and adult release plots, respectively, compared against the control plot [57]. Since the larval stage does not last more than 14 days at ambient conditions, much of the predation in the larval release plot beyond 21 days after the third release was certainly due to newly metamorphosed adults. The very slight decline in percent aphid reduction in the adult release plot, after 35 days post-release, was probably due to the decline in activity and death of some of these flightless adults.

In summarizing this section (Life stage) using a comparative analysis of the results listed in Table 1, aphid population reduction didn't correlate with ladybird (normal strain) release rate $(r=0.055$; $p=0.81 ; n=22)$; and ladybird larvae were less effective than adults, based on a ratio of aphid population reduction/release rate $(t=2.14 ; \mathrm{df}=20 ; p=0.045$; Figure 3; Table 1). Note that some of the adult releases were inside cages, thereby limiting adult dispersion from plants. In contrast, aphid population reduction was in fact correlated with the release of flightless $H$. axyridis ( $r=0.79$; $p=0.02 ; n=8)$; and larvae were not significantly less effective than adults $(t=1.88 ; \mathrm{df}=6 ; p=0.11$; Figure 4; Table 1). None of the adults of the flightless strain were released into cages. Overall, the ratio of aphid reduction/release rate was greatest (exceeding a value of 150) for ladybird adults of several species of the normal strain, but least (less than a value of 8 ) for adults of a flightless $H$. axyridis strain. This suggests that adults of the normal strain could be more effective (than the flightless strain) in suppressing aphids. Further research is necessary to confirm these results, especially because the number of studies involving releases of the flightless strain are limited in this review.
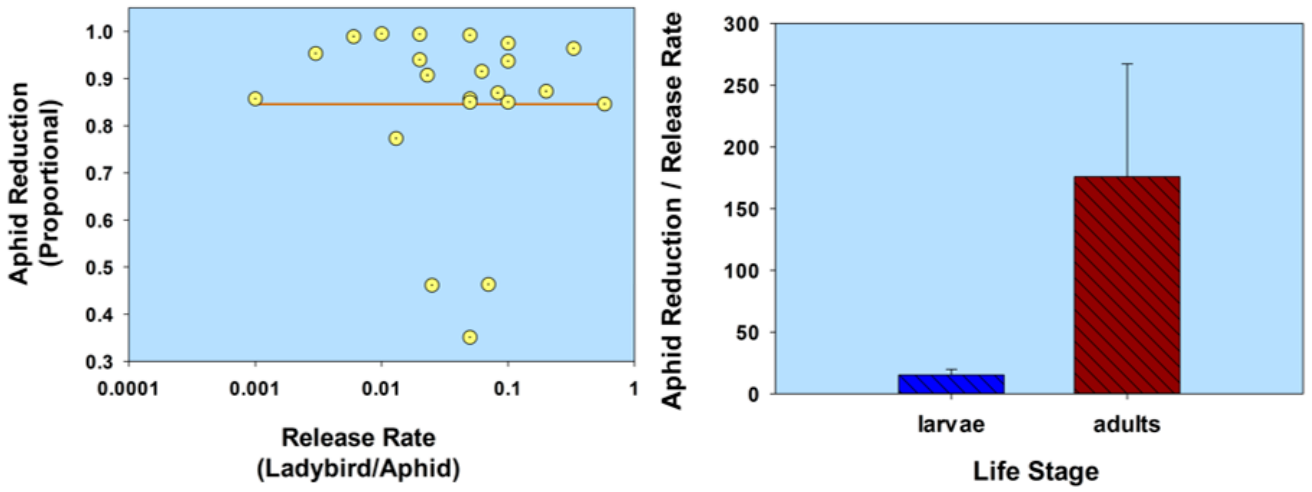

Figure 3. Scatterplot of release rate vs. aphid reduction and bar graph of ladybird life stage (normal strain) vs. the ratio of aphid reduction/release rate. The release rate is plotted on a common logarithmic scale. Data based on five studies and 22 observations (see Table 1).
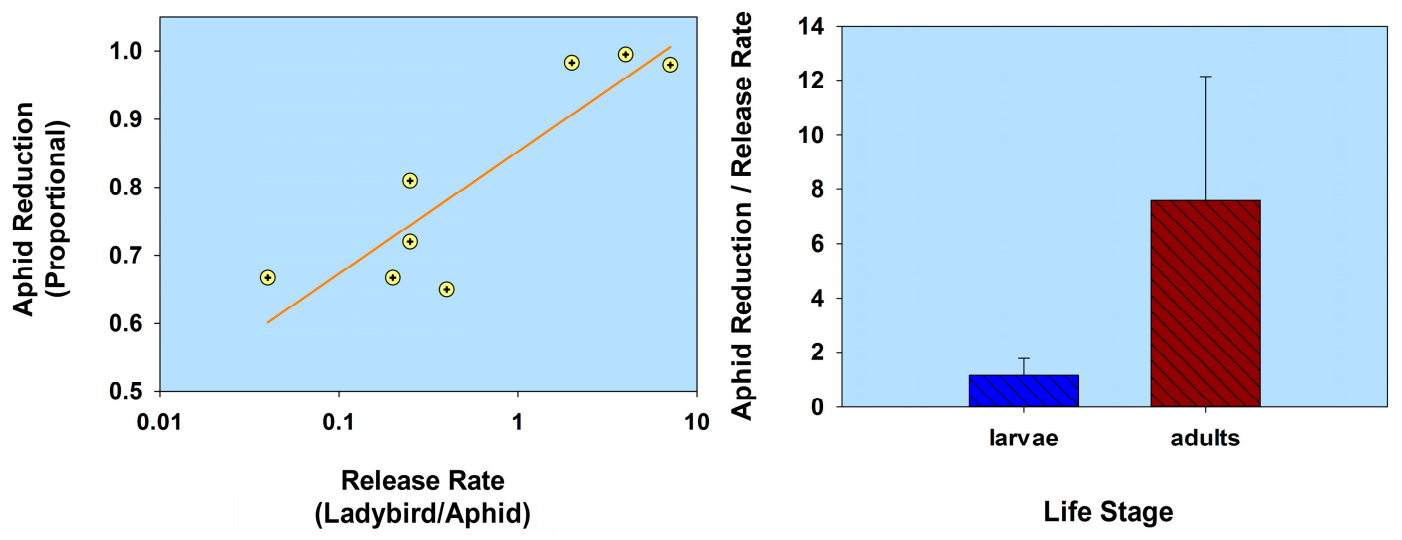

Figure 4. Scatterplot of release rate vs. aphid reduction and bar graph of ladybird life stage (flightless strain) vs. the ratio of aphid reduction/release rate. The release rate is plotted on a common logarithmic scale. Data based on three studies and 8 observations (see Table 1). 


\subsection{Other Aphid Predators}

The presence of other aphid predators on shared host plants could affect ladybird success, if ladybirds avoid these plants. If ladybirds forage on shared host plants, the interaction between predators could result in intraguild predation. Intraguild predation, in which one ladybird species attacks and kills another ladybird or non-ladybird predator, has been documented most often under laboratory conditions [61]. For example, $H$. axyridis larvae and adults are known to function as intraguild predators of other ladybirds and syrphid flies [61-63], although H. axyridis can occasionally serve as intraguild prey for syrphids [63]. Also, H. axyridis larvae are intraguild prey for lacewing Chrysoperla carnea (Stephens) larvae [64,65]. However, research suggests that intraguild predation usually does not affect the ability of predators to suppress pest densities in the field [66].

When intraguild predation is limited, or non-existent, ladybirds can reduce aphid densities in greenhouses in the presence of other aphid predators. The ability of Coccinella transversoguttata Faldermann adults to reduce M. persicae densities in the presence or absence of two hemipteran predators, Geocoris bullatus (Say) and Nabis americoferus (Carayon), was tested on caged sugarbeet, Beta vulgaris vulgaris L. [58]. C. transversoguttata adults reduced M. persicae populations when used alone or when combined with G. bullatus, N. americoferus, or G. bullatus adults. A release ratio of 4:114 (ladybird: aphid) resulted in a decline to less than $1 \mathrm{M}$. persicae per nine plants in six days. When 2 C. transversoguttata were combined with $4 \mathrm{G}$. bullatus or with $4 \mathrm{G}$. bullatus and $4 \mathrm{~N}$. americoferus, it also resulted in a decline to less than $1 M$. persicae in six days. Thus, aphid population reduction was $100 \%$ in all treatments (Table 1). In contrast, the control cages (without $C$. transversoguttata or any other predator species) contained an average of 416 M. persicae within the same time frame [58].

Undoubtedly, ladybirds and other aphid predators will occasionally come in contact with each other in greenhouses. Despite this fact, reliable quantitative data on the suppression of aphid populations under these conditions is scarce.

\subsection{Aphid Parasitoids}

The presence of aphid parasitoids on shared plants could affect the ability of ladybirds to reduce aphid densities. Aphid parasitoids and ladybirds typically interact when ladybirds come in contact with parasitized aphids. In the laboratory, ladybirds (H. axyridis and C. septempunctata larvae and adults) consumed un-parasitized aphids as readily as newly parasitized ones, but did not prefer consuming mummified aphids $[67,68]$.

The frequency in which ladybirds prey on parasitized (and mummified) aphids in greenhouses is difficult to detect and quantify. The paucity of information on the net consequences of intraguild predation (of immature parasitoids) by ladybirds on aphid suppression in greenhouses signals a need for more research on this important topic. Nevertheless, the limited evidence suggests that the combined action of aphid parasitoids and ladybirds has a net positive effect on aphid population suppression (or limiting population growth) on plants. In a preliminary study, the convergent lady beetle H. convergens (10 adults $/ \mathrm{m}^{2}$ ) and the parasitoid Aphidius colemani Viereck (adults at density of 1 adult $/ 15 \mathrm{~m}^{2}$ ) were released in a glasshouse to suppress $A$. gossypii on strawberries [69]. Within one week, the combined effect of the two natural enemies controlled the aphid outbreak [69]. However, the authors did not provide the data on percent aphid reduction in this study.

The ladybird H. axyridis complemented an aphid parasitoid, Aphelinus asychis Walker, in suppressing M. euphorbiae on cut roses Rosa hybrida L. in a replicate cage and open-release (without cages) trial [70]. Larva and adult $H$. axyridis attacked $M$. euphorbiae and $A$. asychis mummies; $H$. axyridis larvae, not adults, showed a preference for killing and consuming aphids rather than mummies. In cages, M. euphorbiae peak densities were $75 \%$ lower when $H$. axyridis and mummies were present together, in comparison to cages with mummies alone. This cage study implies that $H$. axyridis complements the action of A. asychis despite the consumption of some of the parasitoid mummies. Note that $H$. axyridis adults escaped from the greenhouse after the first trial through a poorly fitting screen over the exhaust fan. After refitting the screen, a second release was more successful, with the establishment of adults 
which reproduced on plants. Soon after peak $H$. axyridis density was observed in the greenhouse, M. euphorbiae densities decreased more than 90\% [70]. Perhaps the combination of ladybirds and parasitoids exerted an additive effect on aphid control. Note that the authors mentioned that caution must be used when interpreting the results of this study, as the greenhouse release was not replicated and it did not include a control greenhouse (where $H$. axyridis was not released).

Researchers released C. septempunctata larvae and adults to suppress primarily $A$. gossypii and A. craccivora on sweet pepper (C. annuum) [60]. In addition, they released the parasitoid A. colemani to suppress the aphid M. persicae in the same greenhouse. They found that A. colemani was capable of controlling low density populations of $M$. persicae. The authors did not indicate if $C$. septempunctata had a positive or negative effect on $A$. colemani. An ideal scenario would be the co-existence of ladybirds and aphid parasitoids with limited or no intraguild predation. The ability of aphid parasitoids to detect aphid aggregations in which a ladybird is foraging, or has been foraging, and to avoid those aggregations, has been revealed via laboratory and greenhouse cage experiments [71]. Perhaps adult aphid parasitoids are capable of detecting chemical signals left behind on foliage by ladybird beetles [72]. Females of three parasitoid species, Aphidius eadyi (Stary, Gonzalez, and Hall), Aphidius ervi (Haliday), and Praon volucre (Haliday), detected chemical trails on leaves visited by $C$. septempunctata and A. bipunctata [72].

In summarizing this section, ladybird predation of parasitized aphids (mummies) can occur on crop plants in greenhouses, but the net effect on aphid suppression is often positive or neutral, rather than negative. The actions of ladybirds and aphid parasitoids can increase the net negative effect on aphid population density. More research is necessary to convincingly demonstrate that the combination of ladybirds and parasitoids is more effective than either on their own for aphid suppression.

\subsection{Foraging and Aphid-Tending Ants}

The presence of ants on shared plants could affect the ability of ladybirds to reduce aphid densities. Antagonistic encounters between ants (Formicidae) and ladybirds have been reported most often on plants in open field conditions or in highly manipulated experiments in the laboratory. Foraging, predatory ants can negatively affect predation potential of ladybirds, when ants attack and kill larvae and deter adults from searching for aphids [73]. For example, workers of the red imported fire ant Solenopsis invicta (Buren) reduced the survival of ladybirds (C. septempunctata and H. convergens larvae) by $50 \%$ on cotton G. hirsutum plants in cages, in comparison to controls (cotton plants in cages without fire ants) [74].

The mutualism between some ant and aphid species has been recognized for decades. Ants tend aphids for their honeydew and aggressively ward-off ladybirds, foraging for aphids [42]. Thus, ants protect the aphids from ladybird predation $[42,43,75,76]$. The disruption of ladybird predation by aphid-tending ants [20,42] is a major concern. Published research to document the impact of aphid-tending ants on ladybird predation in greenhouses has been scant. In companion studies, fire ant workers tended the cotton aphid A. gossypii in caged tests and ladybird C. septempunctata and $H$. convergens larvae survival was reduced by $84 \%$ to $93 \%$ on cotton plants infested with $A$. gossypii in the presence of fire ants, as compared to when fire ants were absent [44,77].

Methods of subduing ant aggression against ladybird beetles are necessary to realize the full predation capacity of many ladybird species under pest management regimes in protected plant culture, when pesticides are not used. One possibility could involve using sticky barriers around the periphery and base of the crop plant [78,79]. An alternative, non-physical method could involve releasing ladybird species that do not elicit aggressive behavior in tending or foraging ants. The ability of several ladybird species in the tribe Scymnini, e.g., Scymnus species, to forage on aphid-infested plants and reduce aphid populations, even in the presence of tending ants, has been documented in field and laboratory studies [80-82]. Chemicals in the waxy covering on the cuticle of Scymnus larvae (and other Scymnini) could camouflage them from ants [83]. Aphid-tending ants are likely attracted to a mixture of hydrocarbons on the cuticle of aphids (and other Homoptera) that they tend for 
honeydew [84]. It is possible that some of the same hydrocarbons on the cuticle of aphids are present on the cuticle and the waxy covering on Scymnini larvae. Aphidophagous ladybird larvae and adults in the tribe Coccinellini (e.g., Adalia, Coleomegilla, Harmonia, and Coccinella species) are not camouflaged from ant aggression; they do not have a wax covering. More research is necessary to document the chemical (molecular) basis of this camouflage hypothesis and to manipulate ant-aphid-ladybird densities in greenhouse experiments.

To summarize this section, methods of subduing ant aggression against ladybird beetles on aphid infested plants are necessary to realize the full predation capacity of many ladybird species under organic management regimes in protected plant culture (greenhouses), without deploying pesticides. The predation capacity of some aphidophagous ladybird species (e.g., in the genus Scymnus) seems to be undeterred by ants. Little or no research on the efficacy of Scymnus species under greenhouse conditions in the presence or absence of aphid-tending ants has been reported, to our knowledge. More research on this topic is necessary.

\section{Concluding Remarks}

This review highlighted the effectiveness of several ladybird species as predators of aphids in greenhouses (and glasshouses). Aphid population reduction exceeded 50\% in most studies and ladybird release rates usually did not correlate with aphid reduction. The ratio of aphid reduction/release rate was slightly less for larvae than for adults in some studies, suggesting that larvae were less effective (than adults) in suppressing aphids. Note that some of the adult releases were inside cages, thereby limiting adult dispersion from plants. Overall, the ratio of aphid reduction/release rate was greatest (exceeding a value of 150) for ladybird adults of several species of the normal strain, but least (less than a value of 8 ) for adults of a flightless $H$. axyridis strain. This may suggest that adults of the normal strain (rather than the flightless strain) were more effective aphid predators in greenhouses.

Based on the limited number of species, and available studies, it was not clear which species was most effective. A comparison of predation capacity, voracity, body size, and tolerance to temperature extremes, amongst species, could help predict which species would be most effective in greenhouses. Many attack a range of aphid species and could be equally effective, if host plant defenses (e.g., leaf trichomes) do not disrupt ladybird foraging behavior. Integrating plant defenses with natural enemies to suppress arthropod pests provides challenges and opportunities [85].

From a practical standpoint, the choice of which species to use may heavily depend on the ease of rearing. For augmentative releases, mass rearing would be necessary to supply the large quantity of high-quality individuals required to reduce aphid densities [86]. Note that $H$. axyridis has been mass-produced and sold commercially for aphid control. Unfortunately, because of the rapid global expansion and negative effects that this species has purportedly had on other ladybirds (through intraguild predation), commercial production and sale of H. axyridis has waned. Although a flightless $H$. axyridis strain has been developed and proven effective for aphid control $[87,88]$, it may or may not alleviate concerns of adults escaping from greenhouses and establishing themselves in the neighboring landscape [89].

Because of the limited availability of mass-produced aphidophagous ladybirds currently on the market, a few biocontrol producers and retailers are involved in the acquisition and sale of field-collected, overwintered H. convergens adults to growers in North America. Adults are harvested from the Sierra Nevada (western USA) foothills each year [90]. Many of these adults are still in a physiological diapause state upon removal from overwintering sites. As reported previously, $H$. convergens adults have a strong flight propensity and tend to disperse from release sites within a few days [19]. Their effectiveness in reducing aphid populations in greenhouses needs further study. However, releases of field-collected, overwintered $H$. convergens adults, at extremely high release rates, did provide some level of aphid control in experimental nurseries [91]. 
Intraguild interactions between ladybirds and other predators, as well as aphid parasitoids, requires further study. Nevertheless, this review provides some evidence that intraguild predation does not deter ladybird predation of aphids. More research is necessary to determine if intraguild predation between ladybirds and generalist predators, such as minute pirate bugs, hoverflies, and lacewings (which are also sold by biocontrol companies for aphid control), affects ladybird efficacy under greenhouse conditions. Interestingly, this review also provides evidence that ladybird predation of parasitoids (developing inside aphid prey) often does not hinder the suppression of aphid populations on plants.

Encounters between ladybirds and foraging or aphid-tending ants in greenhouses has not been thoroughly studied. The few available studies clearly reveal that ants hinder most ladybirds, especially larvae, from attacking aphids. Physical barriers will be necessary to curb the entry of ants into greenhouses. Development of alternative methods to reduce ant aggression towards ladybirds on aphid-infested plants is also necessary. In addition, exploring the possibilities of mass producing and deploying ladybirds (e.g., some Scymnus species) that do not elicit ant aggression would be a worthwhile line of research.

The conditions for successful aphid control by ladybirds in greenhouses has been reviewed. Despite the challenges, using ladybirds to manage aphid populations in greenhouses and similar protective structures is encouraged.

Acknowledgments: Juan A. Morales-Ramos and M. Guadalupe Rojas reviewed an earlier version of this manuscript. Three anonymous peer reviewers provided valuable comments and suggestions on how to improve the text. Jean-Louis Hemptinne translated portions of a relevant publication; Ivo Hodek and Antoon J. M. Loomans sent reprints of important publications. The US Government has the right to retain a nonexclusive, royalty free license in and to any copyright of this article. Mention of a commercial or proprietary product does not constitute an endorsement of the product by the USDA. USDA-ARS is an equal opportunity provider and employer. This research was supported by funds from the USDA-ARS, Southeast Area.

Conflicts of Interest: The author declares no conflicts of interest.

\section{References}

1. Whitwer, S.H.; Castilla, N. Protected cultivation of horticultural crops worldwide. HortTechnology 1995, 5, 6-23.

2. Gullino, M.L.; Albajes, R.; van Lenteren, J.C. Setting the stage: Characteristics of protected cultivation and tools for sustainable crop protection, Chapter 1. In Integrated Pest and Disease Management in Greenhouse Crops; Albajes, R., Gullino, M.L., van Lenteren, J.C., Eds.; Kluwer Academic Publishers: Dordrecht, The Netherlands, 1999; pp. 1-15.

3. Pilkington, L.J.; Messelink, G.; van Lenteren, J.C.; Le Mottee, K. “Protected Biological Control”—Biological pest management in the greenhouse industry. Biol. Control 2010, 52, 216-220. [CrossRef]

4. Messelink, G.J.; Bennison, J.; Alomar, O.; Ingegno, B.L.; Tavella, L.; Shipp, L.; Palevsky, E.; Wäckers, F.L. Approaches to conserving natural enemy populations in greenhouse crops: Current methods and future prospects. BioControl 2014, 59, 377-393. [CrossRef]

5. Blackman, R.L.; Eastop, V.F. Taxonomic issues, Chapter 1. In Aphids as Crop Pests; van Emden, H.F., Harrington, R., Eds.; CAB International: Oxfordshire, UK, 2007; pp. 1-29.

6. Blümel, S. Biological control of aphids on vegetable crops. In Biological Control in Protected Culture; Heinz, K.M., Van Driesche, R.G., Parrella, M.P., Eds.; Ball Publ.: Batavia, IL, USA, 2004; pp. 297-312.

7. Chau, A.; Heinz, K.M. Biological control of aphids on ornamental crops. In Biological Control in Protected Culture; Heinz, K.M., Van Driesche, R.G., Parrella, M.P., Eds.; Ball Publ.: Batavia, IL, USA, 2004; pp. $277-295$.

8. Freeman, S.; Nicoli, G. Strawberries, Chapter 32. In Integrated Pest and Disease Management in Greenhouse Crops; Albajes, R., Gullino, M.L., van Lenteren, J.C., Eds.; Kluwer Academic Publishers: Dordrecht, The Netherlands, 1999; pp. 454-472.

9. Sewell, G.H.; Storch, R.H.; Manzer, F.E.; Forsythe, H.Y., Jr. The relationship between coccinellids and aphids in the spread of potato leafroll virus in a greenhouse. Am. Potato J. 1990, 67, 865-868. [CrossRef]

10. Quisenberry, S.S.; Ni, X. Feeding injury, Chapter 13. In Aphids as Crop Pests; van Emden, H.F., Harrington, R., Eds.; CAB International: Oxfordshire, UK, 2007; pp. 331-352. 
11. Katis, N.I.; Tsitsipis, J.A.; Stevens, M.; Powell, G. Transmission of plant viruses, Chapter 14. In Aphids as Crop Pests; van Emden, H.F., Harrington, R., Eds.; CAB International: Oxfordshire, UK, 2007; pp. 353-390.

12. Scopes, N.E.A. The evaluation and use of predators for protected cropping. Ann. Appl. Biol. 1975, 80, $123-124$. [CrossRef]

13. Yang, N.-W.; Zang, L.-S.; Wang, S.; Guo, J.-Y.; Xu, H.-X.; Zhang, F.; Wan, F.-H. Biological pest management by predators and parasitoids in the greenhouse vegetables in China. Biol. Control 2014, 68, 92-102. [CrossRef]

14. Boivin, G.; Hance, T.; Brodeur, J. Aphid parasitoids in biological control. Can. J. Plant Sci. 2012, 92, 1-12. [CrossRef]

15. Rabasse, J.-M.; van Steenis, M.J. Biological control of aphids, Chapter 16. In Integrated Pest and Disease Management in Greenhouse Crops; Albajes, R., Gullino, M.L., van Lenteren, J.C., Elad, Y., Eds.; Kluwer Academic Publishers: Dordrecht, The Netherlands, 1999; pp. 235-253.

16. Prado, S.G.; Jandricic, S.E.; Frank, S.D. Ecological interactions affecting the efficacy of Aphidius colemani in greenhouse crops. Insects 2015, 6, 538-575. [CrossRef] [PubMed]

17. Gamarra, D.C.; Bueno, H.P.; Auad, A.M. Efecto de los tricomas glandulares de Solanum berthaultii en el parasitismo de Aphidius colemani (Hymenoptera: Aphidiidae) sobre Myzus persicae (Homoptera: Aphididae). Vedalia 1997, 4, 21-24. (In Spanish).

18. Colfer, R.G.; Rosenheim, J.A. Predation on immature parasitoids and its impact on aphid suppression. Oecologia 2001, 126, 292-304. [CrossRef]

19. Hagen, K.S. Biology and ecology of predaceous Coccinellidae. Annu. Rev. Entomol. 1962, 7, 289-326. [CrossRef]

20. Hagen, K.S.; van den Bosch, R. Impact of pathogens, parasites, and predators on aphids. Annu. Rev. Entomol. 1968, 13, 325-384. [CrossRef]

21. Hodek, I. Food relationships, Chapter 6. In Ecology of Coccinellidae; Hodek, I., Honěk, A., Eds.; Kluwer Academic Publishers: Boston, MA, USA, 1996; pp. 143-248.

22. Obrycki, J.J.; Kring, T.J. Predaceous Coccinellidae in biological control. Annu. Rev. Entomol. 1998, 43, $295-321$. [CrossRef] [PubMed]

23. Brown, M.W. Role of aphid predator guild in controlling spirea aphid populations on apple in West Virginia, USA. Biol. Control 2004, 29, 189-198. [CrossRef]

24. Mignault, M.-P.; Roy, M.; Brodeur, J. Soybean aphid predators in Québec and the suitability of Aphis glycines as prey for three Coccinellidae. BioControl 2006, 51, 89-106. [CrossRef]

25. Obrycki, J.J.; Harwood, J.D.; Kring, T.J.; O’Neil, R.J. Aphidophagy by Coccinellidae: Application of biological control in agroecosystems. Biol. Control 2009, 51, 244-254. [CrossRef]

26. Ragsdale, D.W.; Landis, D.A.; Brodeur, J.; Heimpel, G.E.; Desneux, N. Ecology and management of the soybean aphid in North America. Annu. Rev. Entomol. 2011, 56, 375-399. [CrossRef] [PubMed]

27. Dutcher, J.D.; Karar, H.; Abbas, G. Seasonal abundance of aphids and aphidophagous insects in pecan. Insects 2012, 3, 1257-1270. [CrossRef] [PubMed]

28. Long, E.Y.; Finke, D.L. Contribution of predator identity to the suppression of herbivores by a diverse predator assemblage. Environ. Entomol. 2014, 43, 569-576. [CrossRef] [PubMed]

29. Mills, N.J. Satiation and the functional response: A test of a new model. Ecol. Entomol. 1982, 7, 305-315. [CrossRef]

30. Dixon, A.F.G.; Hemptinne, J.-L.; Kindlmann, P. Effectiveness of ladybirds as biological control agents: Patterns and processes. Entomophaga 1997, 42, 71-83. [CrossRef]

31. Dixon, A.F.G. Insect Predator-Prey Dynamics: Ladybird Beetles E Biological Control; Cambridge Univ. Press: Cambridge, UK, 2000.

32. Magro, A.; Hemptinne, J.L.; Codreanu, P.; Grosjean, S.; Dixon, A.F.G. Does the satiation hypothesis account for the differences in efficacy of coccidophagous and aphidophagous ladybird beetles in biological control? A test with Adalia bipunctata and Cryptolaemus montrouzieri. BioControl 2002, 47, 537-543. [CrossRef]

33. Kindlmann, P.; Yasuda, H.; Kajita, Y.; Sato, S.; Dixon, A.F.G. Predator efficiency reconsidered for a ladybird-aphid system. Front. Ecol. Evol. 2015. [CrossRef]

34. Wyss, E.; Villiger, M.; Hemptinne, J.L.; Muller-Scharer, H. Effects of augmentative releases of eggs and larvae of the ladybird beetle, Adalia bipunctata, on the abundance of the rosy apple aphid, Dysaphis plantaginea, in organic apple orchards. Entomol. Exp. Appl. 1999, 90, 167-173. [CrossRef]

35. Kehrli, P.; Wyss, E. Effects of augmentative releases of the coccinellid, Adalia bipunctata, and of insecticide treatments in autumn on the spring population of aphids of the genus Dysaphis in apple orchards. Entomol. Exp. Appl. 2001, 99, 245-252. [CrossRef] 
36. Kirby, W.; Spence, W. An Introduction to Entomology: Or Elements of the Natural History of Insects, 3rd ed.; Longman, Hurst, Rees, Orme, and Brown: London, UK, 1818; Volume 1.

37. Van Driesche, R.G.; Heinz, K.M. An overview of biological control in protected culture. In Biological Control in Protected Culture; Heinz, K.M., Van Driesche, R.G., Parrella, M.P., Eds.; Ball Publ.: Batavia, IL, USA, 2004; pp. 1-24.

38. Frazer, B.D. Coccinellidae. In Aphids: Their Biology, Natural Enemies, and Control, Vol. B; Minks, A.K., Harrewijn, P., Eds.; Elsevier: New York, NY, USA, 1988; pp. 231-247.

39. Yano, E. Ecological considerations for biological control of aphids in protected culture. Popul. Ecol. 2006, 48, 333-339. [CrossRef]

40. Powell, W.; Pell, J.K. Biological control, Chapter 18. In Aphids as Crop Pests; van Emden, H.F., Harrington, R., Eds.; CAB International: Oxfordshire, UK, 2007; pp. 469-513.

41. Riddick, E.W.; Simmons, A.M. Do plant trichomes cause more harm than good to predatory insects? Pest Manag. Sci. 2014, 70, 1655-1665. [CrossRef] [PubMed]

42. Way, M.J. Mutualism between ants and honeydew-producing Homoptera. Annu. Rev. Entomol. 1963, 8, 307-344. [CrossRef]

43. Majerus, M.E.N.; Sloggett, J.J.; Godeau, J.-F.; Hemptinne, J.L. Interactions between ants and aphidophagous and coccidophagous ladybirds. Popul. Ecol. 2007, 49, 15-27. [CrossRef]

44. Kaplan, I.; Eubanks, M.D. Aphids alter the community-wide impact of fire ants. Ecology 2005, 86, 1640-1649. [CrossRef]

45. Shannag, H.K.; Obeidat, W.M. Interaction between plant resistance and predation of Aphis fabae (Homoptera: Aphididae) by Coccinella septempunctata (Coleoptera: Coccinellidae). Ann. Appl. Biol. 2008, 152, 331-337. [CrossRef]

46. Chang, G.C.; Eigenbrode, S.D. Delineating the effects of a plant trait on interactions among associated insects. Oecologia 2004, 139, 123-130. [CrossRef] [PubMed]

47. Obrycki, J.J.; Tauber, M.J. Natural enemy activity on glandular pubescent potato plants in the greenhouse: An unreliable predictor of effects in the field. Environ. Entomol. 1984, 13, 679-683. [CrossRef]

48. Gurney, B.; Hussey, N.W. Evaluation of some coccinellid species for the biological control of aphids in protected cropping. Ann. Appl. Biol. 1970, 65, 451-458. [CrossRef]

49. Boiça, J.A.; Santos, T.M.; Kuranishi, A.K. Desenvolvimento larval e capacidade predatória de Cycloneda sanguinea (L.) e Hippodamia convergens Guérin-Men. alimentadas com Aphis gossypii Glover sobre cultivars de algodoeiro. Acta Sci. Agron. 2004, 26, 239-244. (In Portuguese).

50. Hämäläinen, M. Control of aphids on sweet peppers, chrysanthemums and roses in small greenhouses using the ladybeetles Coccinella septempunctata and Adalia bipunctata (Col., Coccinellidae). Ann. Agric. Fenn. 1977, 16, 117-131.

51. Kuznetsov, V.N.; Hong, P. Employment of Chinese coccinellids in biological control of aphids in greenhouse in Primorye. Far Eastern Entomol. 2002, 119, 1-5.

52. Seo, M.J.; Youn, Y.N. Effective preservation methods of the Asian ladybird, Harmonia axyridis (Coleoptera: Coccinellidae), as an application strategy for the biological control of aphids. J. Asia-Pac. Entomol. 2002, 5, 209-214. [CrossRef]

53. Rondon, S.I.; Cantliffe, D.J.; Price, J.F. Population dynamics of the cotton aphid, Aphis gossypii (Homoptera: Aphididae), on strawberries grown under protected culture. Fla. Entomol. 2005, 88, 152-158. [CrossRef]

54. LaRock, D.R.; Mirdad, Z.; Ellington, J.J.; Carillo, T.; Southward, M. Control of green peach aphids Myzus persicae with lady beetles Harmonia axyridis on Chile Capsicum annum in the greenhouse. Southwest. Entomol. 2003, 28, 249-253.

55. Kuroda, T.; Miura, K. Comparison of the effectiveness of two methods for releasing Harmonia axyridis (Pallas) (Coleoptera: Coccinellidae) against Aphis gossypii Glover (Homoptera: Aphididae) on cucumbers in a greenhouse. Appl. Entomol. Zool. 2003, 38, 271-274. [CrossRef]

56. Adachi-Hagimori, T.; Shibao, M.; Tanaka, H.; Seko, T.; Miura, K. Control of Myzus persicae and Lipaphis erysimi (Hemiptera: Aphididae) by adults and larvae of a flightless strain of Harmonia axyridis (Coleoptera: Coccinellidae) on non-heading Brassica cultivars in the greenhouse. BioControl 2011, 56, 207-213. [CrossRef]

57. Seko, T.; Sumi, A.; Nakano, A.; Kameshiro, M.; Kaneda, T.; Miura, K. Suppression of aphids by augmentative release of larvae of flightless Harmonia axyridis. J. Appl. Entomol. 2014, 138, 326-337. [CrossRef] 
58. Tamaki, G.; Weeks, R.E. Efficiency of three predators, Geocoris bullatus, Nabis americoferus, and Coccinella transversoguttata, used alone or in combination against three insect prey species, Myzus persicae, Ceramica picta, and Mamestra configurata, in a greenhouse study. Environ. Entomol. 1972, 1, 258-263. [CrossRef]

59. Valério, E.; Cecílio, A.; Mexia, A. Population dynamics of aphids (Homoptera: Aphididae) and beneficial organisms on protected strawberry crops. Boletín Sanidad Vegetal Plagas 2007, 33, 153-161.

60. Valério, E.; Cecílio, A.; Mexia, A. Interactions between aphid species and beneficial organisms in sweet pepper protected crop. Bol. Sanid. Veg. Plagas 2007b, 33, 143-152.

61. Lucas, É. Intraguild interactions, Chapter 7. In Ecology and Behaviour of the Ladybird Beetles (Coccinellidae), 1st ed.; Hodek, I., van Emden, H.F., Honěk, A., Eds.; Blackwell Publishing Ltd.: West Sussex, UK, 2012; pp. 343-374.

62. Yang, F.; Wang, Q.; Wang, D.; Xu, B.; Xu, J.; Lu, Y.; Harwood, J.D. Intraguild predation among three common coccinellids (Coleoptera: Coccinellidae) in China: Detection using DNA-based gut-content analysis. Environ. Entomol. 2016. [CrossRef] [PubMed]

63. Ingels, B.; De Clercq, P. Effect of size, extraguild prey and habitat complexity on intraguild interactions: A case study with the invasive ladybird Harmonia axyridis and the hoverfly Episyrphus balteatus. BioControl 2011, 56, 871-882. [CrossRef]

64. Nedved, O.; Fois, X.; Ungerova, D.; Kalushkov, P. Alien vs. predator-The native lacewing Chrysoperla carnea is the superior intraguild predator in trials against the invasive ladybird Harmonia axyridis. Bull. Insectol. 2013, 66, 73-78.

65. Noppe, C.; Michaud, J.P.; De Clercq, P. Intraguild predation between lady beetles and lacewings: Outcomes and consequences vary with focal prey and arena of interaction. Ann. Entomol. Soc. Am. 2012, 105, 562-571. [CrossRef]

66. Janssen, A.; Montserrat, M.; HilleRisLambers, R.; de Roos, A.M.; Pallini, A.; Sabelis, M.W. Intraguild predation usually does not disrupt biological control. In Trophic and Guild Interactions in Biological Control; Brodeur, J., Boivin, G., Eds.; Springer: Dordrecht, The Netherlands, 2006; pp. 21-44.

67. Xue, Y.; Bahlai, C.A.; Frewin, A.; McCreary, C.M.; Des Marteaux, L.E.; Schaafsma, A.W.; Hallett, R.H. Intraguild predation of the aphid parasitoid Aphelinus certus by Coccinella septempunctata and Harmonia axyridis. BioControl 2012, 57, 627-634. [CrossRef]

68. Fu, W.; Yu, X.; Ahmed, N.; Zhang, S.; Liu, T. Intraguild predation on the aphid parasitoid Aphelinus asychis by the ladybird Harmonia axyridis. BioControl 2017, 62, 61-70. [CrossRef]

69. Sterk, G.; Meesters, P. IPM on strawberries in glasshouses and plastic tunnels in Belgium, new possibilities. In Proceedings of the Third International Strawberry Symposium, Veldhoven, The Netherlands, 29 April-4 May 1997; pp. 905-911.

70. Snyder, W.E.; Ballard, S.N.; Yang, S.; Clevenger, G.M.; Miller, T.D.; Ahn, J.J.; Hatten, T.D.; Berryman, A.A. Complementary biocontrol of aphids by the ladybird beetle Harmonia axyridis and the parasitoid Aphelinus asychis on greenhouse roses. Biol. Control 2004, 30, 229-235. [CrossRef]

71. Meisner, M.; Harmon, J.P.; Harvey, C.T.; Ives, A.R. Intraguild predation on the parasitoid Aphidius ervi by the generalist predator Harmonia axyridis: The threat and its avoidance. Entomol. Exp. Appl. 2011, 138, 193-201. [CrossRef]

72. Nakashima, Y.; Birkett, M.A.; Pye, B.J.; Powell, W. Chemically mediated intraguild predator avoidance by aphid parasitoids: Interspecific variability in sensitivity to semiochemical trails of ladybird predators. J. Chem. Ecol. 2006, 32, 1989-1998. [CrossRef] [PubMed]

73. Oliver, T.H.; Jones, I.; Cook, J.M.; Leather, S.R. Avoidance responses of an aphidophagous ladybird, Adalia bipunctata, to aphid-tending ants. Ecol. Entomol. 2008, 33, 523-528. [CrossRef]

74. Eubanks, M.D.; Blackwell, S.A.; Parrish, C.J.; Delamar, Z.D.; Hull-Sanders, H. Intraguild predation of beneficial arthropods by red imported fire ants in cotton. Environ. Entomol. 2002, 31, 1168-1174. [CrossRef]

75. El-Ziady, S.; Kennedy, J.S. Beneficial effects of the common garden ant, Lasius niger L., on the black bean aphid, Aphis fabae Scopoli. Proc. R. Entomol. Soc. Lond. A 1956, 31, 61-65. [CrossRef]

76. Powell, B.E.; Silverman, J. Impact of Linepithema humile and Tapinoma sessile (Hymenoptera: Formicidae) on three natural enemies of Aphis gossypii (Hemiptera: Aphididae). Biol. Control 2010, 54, 285-291. [CrossRef]

77. Kaplan, I.; Eubanks, M.D. Disruption of cotton aphid (Homoptera: Aphididae)—Natural enemy dynamics by red imported fire ants (Hymenoptera: Formicidae). Environ. Entomol. 2002, 31, 1175-1183. [CrossRef] 
78. Piñol, J.; Espadaler, X.; Cañellas, N.; Pérez, N. Effects of the concurrent exclusion of ants and earwigs on aphid abundance in an organic citrus grove. BioControl 2009, 54, 515-527. [CrossRef]

79. Romeu-Dalmau, C.; Espadaler, X.; Piñol, J. A simple method to differentially exclude ants from tree canopies based on ant body size. Methods Ecol. Evol. 2010, 1, 188-191. [CrossRef]

80. Völkl, W.; Vohland, K. Wax covers in larvae of two Scymnus species: Do they enhance coccinellid larval survival? Oecologia 1996, 107, 498-503. [CrossRef] [PubMed]

81. Kaneko, S. Aphid-attending ants increase the number of emerging adults of the aphid's primary parasitoid and hyperparasitoids by repelling intraguild predators. Entomol. Sci. 2002, 5, 131-146.

82. Schwartzberg, E.G.; Haynes, K.F.; Johnson, D.W.; Brown, G.C. Wax structures of Scymnus louisianae attenuate aggression from aphid-tending ants. Environ. Entomol. 2010, 39, 1309-1314. [CrossRef] [PubMed]

83. Pope, R.D. Wax production by coccinellid larvae (Coleoptera). Syst. Entomol. 1979, 4, 171-196. [CrossRef]

84. Lohman, D.J.; Liao, Q.; Pierce, N.E. Convergence of chemical mimicry in a guild of aphid predators. Ecol. Entomol. 2006, 31, 41-51. [CrossRef]

85. Peterson, J.A.; Ode, P.J.; Oliveira-Hofman, C.; Harwood, J.D. Integration of plant defense traits with biological control of arthropod pests: Challenges and opportunities. Front. Plant Sci. 2016. [CrossRef] [PubMed]

86. Riddick, E.W.; Chen, H. Production of coleopteran predators, Chapter 2. In Mass Production of Beneficial Organisms: Invertebrates and Entomopathogens; Morales-Ramos, J.A., Rojas, M.G., Shapiro-Ilan, D.I., Eds.; Academic Press: London, UK, 2014; pp. 17-55.

87. Riddick, E.W. Spotlight on the positive effects of the ladybird Harmonia axyridis on agriculture. BioControl 2016. [CrossRef]

88. Seko, T.; Abe, J.; Miura, K.; Hikawa, M. The contribution of a beneficial insectary plant Scaevola aemula to survival and long-term establishment of flightless Harmonia axyridis in greenhouses. BioControl 2017, 62, 221-231. [CrossRef]

89. Turgeon, J.; Tayeh, A.; Facon, B.; Lombaert, E.; De Clercq, P.; Berkvens, N.; Lundgren, J.G.; Estoup, A. Experimental evidence for the phenotypic impact of admixture between wild and biocontrol Asian ladybird (Harmonia axyridis) involved in the European invasion. J. Evol. Biol. 2011, 24, 1044-1052. [CrossRef] [PubMed]

90. Carnes, E.K. Collecting ladybirds (Coccinellidae) by the ton. Calif. State Comm. Hort. Mon. Bull. 1912, 1, 71-81.

91. Flint, M.L.; Dreistadt, S.H. Interactions among convergent lady beetle (Hippodamia convergens) releases, aphid populations, and rose cultivar. Biol. Control 2005, 34, 38-46. [CrossRef] 